\title{
The Impact of Collocation Activities on Iranian Intermediate EFL Learners' Knowledge of Vocabulary
}

\section{Sanaz Pakdaman ${ }^{1} \&$ Abbas Pourhosein Gilakjani*2}

\section{* Correspondence: \\ abbas.pourhossein@yahoo.com \\ 1. Department of English Language \\ Translation, Lahijan Branch, Islamic \\ Azad University, Lahijan, Iran}

Received: 17 June 2019

Revision: 18 October 2019

Accepted: 30 November 2019

Published online: 20 December 2019

\begin{abstract}
The primary aim of this study was to open up new ways with which teachers could help learners improve their knowledge of vocabulary via collocation activities. This study investigated the effect of collocation activities on Iranian intermediate EFL learners' vocabulary knowledge in order to solve their vocabulary problems. To this end, 60 female students from Pardis Institute in Lahijan, Iran participated in this study. They were divided into two groups of 30 , one as an experimental group that received collocation activities as the treatment and a control group which received traditional method of vocabulary instruction. The researchers used a quasiexperimental, pre-test/post-test control group design. The data were analyzed using an Independent Samples T-test and a series of paired Samples T-tests. The findings of this study showed that collocation activities improved significantly participant learners' vocabulary knowledge. The findings from paired-sample t-test indicated that the learners in the experimental group outperformed the control group in vocabulary knowledge.
\end{abstract}

Keywords: collocation, vocabulary, knowledge of vocabulary, EFL learners 


\section{Introduction}

Vocabulary is a central foundation of every sentence in every language. Knowing common words in learning English plays a vital role in improving students' skills in listening, speaking, reading, and writing. According to Waring (2002), building a reliable body of vocabulary knowledge to learn another language linguistically and psychologically is very important and without this reliable knowledge of vocabulary, little can be learned in a foreign language and also by structuring a brilliant vocabulary knowledge domain quite actively, one can be capable of functioning in that language completely. Three reasons for the importance of vocabulary skills have been introduced by Nation (2001). First, it is a necessary part of reading comprehension. Second, by vocabulary learning, learners can get more academic success. Third, it prepares success in life. Students' vocabulary knowledge can be developed through a variety of ways. They learn words from others such as parents, teachers, peers, and contexts. Furthermore, they learn words through their knowledge of word parts by using resources such as dictionaries or glossaries.

L2 learners can improve vocabulary knowledge formally in the classroom and informally through communication with others and by means of out of class activities. New words can be presented with collocation technique which is extremely important for acquiring vocabulary and has yet to be exploited to its full potential so that students will be able to use these words later in their own performance. Despite the growing interest in teaching collocations in foreign language classes, experimental studies in Iranian foreign language classroom settings are still few. Although vocabulary has been the subject of many studies, few researchers have revealed the effective techniques of vocabulary teaching, especially the effect of using collocations on vocabulary (Ghezelseflou \& Seyedrezaei, 2015).

Words familiarity has been the focus of research on EFL learners' vocabulary progress for many years. Though, the problem of word combinability, as one of the major factors of vocabulary learning, should be tackled more seriously than before (Yunus, Salehi, \& Amini, 2016). But one problem is that it is not easy to define collocations precisely since the available definitions are not stated obviously. Still, collocations have been defined by EFL experts from different viewpoints. Collocation is the way in which words co-occur in natural text in statistically significant ways (Lewis, 2000). In another definition by Nattinger and Decarrio (1992), collocation is explained as strings of specific lexical items that co-occur with a mutual expectancy greater than chance, such as rancid butter.

Gorjian, Moosavinia, Ebrahimi, and Asgariand Hydarei (2011) highlight the significance of vocabulary learning by asserting that learners can develop their listening, speaking, reading, and writing abilities and may ultimately develop comprehension and production in the L2 by vocabulary learning. Several methods and techniques to vocabulary teaching and learning have been presented with the recognition of the significance of vocabulary, and one of those techniques is collocation. Tovar Viera (2017) declare that language instructions should provide opportunities for social interaction, that is, learners can use the new vocabulary within different contexts, by focusing on communication rather than uttering possible well-formed sentences. In order that vocabulary acquisition takes place, its learning needs meaningful interactions, these allow learners to familiarize with the appropriate language use in a given context. Just the contact with the form-meaning connections of words, learners can increase their lexicon, consequently, learners learn words to use productively in different communicative situations.

Jaén (2007) asserts that collocations are very significant part of knowledge of second language acquisition and they are necessary to non-native speakers of English in order to speak or write fluently and accurately. Skrzypek (2009) specifies the importance of collocation by emphasizing that one of the criteria for knowing a word is knowing other words with which it keeps company. As it is clarified by Shin and Nation (2008), one of the reasons as to why learners and teachers should be interested in collocations being that collocations improve learners' language fluency and ensure native-like selection. According to Nattinger (1988), collocations could help students in committing these words to memory and defining the semantic area of a word, and could allow learners to know and to foresee what kinds of words would be found together. Moreover, he gave the reasons of teaching lexical phrases. The most important reason was that teaching lexical phrases would lead to fluency in speaking and writing because they change learners' attention from individual words to larger structures of the discourse and to the social aspects of the interaction.

One of the critical factors in second language acquisition is vocabulary learning and its effective use. As Allen (1983) stated, vocabulary difficulties frequently affect communication and breaks it down when learners do not use the correct words. Achieving language proficiency requires growing one's vocabulary stock (Krashen, 1989) and it seems that greater attention should be paid to issues related to vocabulary learning and teaching as the center of language learning since without vocabulary improvement it is challenging to communicate. Nowzan and Baryaji (2013) express that vocabulary is the main difficulty to many Iranian EFL learners during speaking in English. Lack of vocabulary storage 
is the problem that most of learners are faced with. They usually complain about vocabulary difficulties in reading and translating, in listening to English news, in watching English cartoons, and even in writing a simple letter in a foreign language. They forget words after a few days of memorization. Such problems brought a new idea to the mind of the researchers to see if different methods would improve learning vocabulary.

Nowsan and Baryaji (2013) also believed that vocabulary teaching and learning were often given little importance in EFL education, but now the position of vocabulary looks to be changing. For a longtime, vocabulary learning has been an area of language learning which gives the students the headache. They keep complaining that no longer after they have memorized a word, it evades. Even where instructors have spent too much time to vocabulary teaching, the consequences have been unsatisfactory. Occasionally after several months or even years of English speaking, many of the words most needed have never been learned.

Some EFL learners have sufficient knowledge of English grammar and vocabulary, but they have serious problems with utilizing vocabulary in communication. For instance, "take risk" is an acceptable collocation in English language. Iranian learners who speak Persian say "Risk Kardan" which literally means "do risk" and when it comes to English they regard it in their L1 and in place of "Take risk" they say "do risk." Literally, Iranians say "Do risk" while native speakers of English say "Take risk." Therefore, to develop learners' reading, writing, and speaking skills, they should use collocation in their language skills. In Iran, great attention is paid to grammar not vocabulary during any EFL courses. Learners learn the words separately and memorize them individually by translating them to their mother tongue. Thus, when learners want to use English vocabulary they fail to produce them correctly and figure them out in contexts. Knowing vocabulary and its collocation helps learners to speak about things and to do things (Khoda Reza \& Ashouri, 2016).

\section{Review of the Literature}

In this section, the researchers review previous findings about the impact of collocation activities on learners' knowledge of vocabulary. Lien (2003) studied the effect of collocation teaching on reading comprehension. Her quasiexperimental study has been conducted at a national university in central Taiwan which lasted four-weeks. The results of this study showed that teaching collocation had more positive effects on the participants' reading comprehension than vocabulary teaching and no teaching. In another study, Hsu (2005) explored the effect of explicit collocation teaching on EFL learners' listening comprehension. Accordingly, the participants performed significantly better in listening comprehension after receiving lexical collocation instruction. Hsu (2010) examined the impact of direct collocation instruction on Taiwanese college English majors' reading comprehension and vocabulary learning. Three groups of Taiwanese college English majors were divided based on their academic levels. Each group received (a) a vocabulary pretest, (b) 3 different types of instruction-single-item vocabulary instruction, lexical collocation instruction, and no instruction in separate classes, (c) a reading comprehension test, and (d) 3 vocabulary recall tests (immediate, 1-week delayed, and 2-week delayed). The results of this study revealed that (1) the lexical collocation instruction improves the learners' vocabulary learning more than their reading comprehension across all three academic levels; (2) the treatment of collocation instruction improves the learners' performance on the 3 recall tests, outscoring the other two instruction kinds in the vocabulary retention patterns.

Altinok (2000) carried out a study to investigate the differences between two vocabulary acquisition techniques, collocations and dictionary definition in EFL classes. The participants were 65 intermediate level learners in three classes. The research investigated whether there were any significant differences between the three groups in terms of learning vocabulary items. One of the treatment groups received vocabulary items together with their collocations whereas the other treatment group received just definitions. The control group did not receive any vocabulary presentation. To identify the vocabulary to be utilized in the presentations, two pre-tests were given to the learners. Then, these vocabulary items were presented in two consecutive sessions in two reading texts. After practicing these vocabulary, two post-tests were given learners a day after. Delayed post-tests were given 10 days later to measure remembering. To analyze the results of the post-tests, analysis of variance (ANOVA), and T-tests were done too understand if there were any significant differences between the scores of the three groups. Although the groups revealed differences in the test results, ANOVA indicated that the differences were not statistically significant. This finding represents that using collocations may not help learners in vocabulary learning. The results of the delayed post-tests indicated that means were rather different but ANOVA showed that there were no significant differences among the groups. This implies that collocations may not help learners remember vocabulary items. 
Some studies have been conducted on the impact of collocation activities on learners' knowledge of vocabulary in Iran. Ghonsooli, Pishgaman, and Mahjoobi (2008) examined the effect of teaching collocation on Iranian EFL learners' writing skill. The results showed significant improvement in the students' writing performance due to familiarity with collocation use. Rahimi and Momeni (2012) examined the impact of teaching collocations on English language proficiency. 60 learners took part in a pretest-posttest quasi-experimental design study. For four months, the control group was taught the new words in isolation with traditional techniques like translation and definition. In the experimental group, vocabulary was taught by providing learners with collocations of a specific word by using concordancers and corpus-based activities. After the experiment, both groups participated in a language proficiency test. The results of this study represented that the experimental group outperformed the control group in the posttest, showing that teaching collocations can improve learners' language proficiency.

Yazdandoos, AmalSaleh, and Kafipour (2014) investigated the relationship among knowledge of collocation and reading, writing, speaking, and listening proficiency of Iranian EFL learners. To this end, 50 learners participated in this study and took a test of both lexical and grammatical collocations to measure their collocational knowledge. Then, an International English Language Testing System (IELTS) sample test was administered to find the learners' reading, writing, speaking, and listening proficiency. The results showed that knowledge of collocation can be a predicator for all four language skills. Moreover, knowledge of collocation had a great impact on participants' speaking proficiency. This study confirmed the significant role of collocation knowledge in essential language learning.

Khodareza and Ashouri (2016) investigated the effect of lexical collocation instruction on Iranian intermediate EFL learners' vocabulary size. 84 Iranian learners were chosen and then they were randomly divided into two groups; experimental and control. They were given a test with one-week interval time (a vocabulary size test). The aim was to understand that there was no significant difference between the two groups in terms of their vocabulary prior to the implementation of the particular treatment. Then, lexical collocation was practiced for the experimental group while traditional teaching was used for the control group. The data were collected through the pre-test and post-test of vocabulary tests to the both groups. The findings revealed that the efficiency of the treatment was considerable. This research suggests that lexical collocation instruction is a valuable technique for increasing the vocabulary knowledge. It was also indicated that the experimental group outperformed the control group in using collocations and learning them properly.

Keshavarz and Taherian (2018) examined the effect of explicit instruction of collocations on EFL learners' English proficiency. To this aim, the performance of two groups of EFL learners in the form of time-series evaluation was compared. A pre-test namely Preliminary English Test (PET) was administered to ensure the homogeneity of the participants. The teacher and the textbooks for both groups were similar and in the experimental group, there was an explicit emphasis on collocations in all four language skills. These learners were required to keep track of collocations by taking careful notes and utilizing them in their productive skills to activate and internalize them. They were also taught to transcribe the listening passages of the textbook after the tests were administered in class. The control group was just exposed to collocations. Continuous formative evaluation was used to keep track of the learners' progress towards reaching the intermediate proficiency level. The findings of the study revealed that the experimental group outperformed the control group, implying that teaching collocations lead to improvement in language proficiency.

As stated above, different researches have been conducted with regards to the impact of familiarity with collocation use on the improvement of language proficiency in different skills, but no study has been done in Iranian non-academic setting regarding the impact of collocation activities on Iranian intermediate learners' knowledge of vocabulary. Because of this and in order to fill the gap, this study examined the impact of collocation activities on Iranian intermediate learners' knowledge of vocabulary. To fulfill the objectives of this study, the following research question was proposed:

Do collocation activities have any significant effect on Iranian intermediate EFL learners' knowledge of vocabulary?

\section{Methodology}

\subsection{Design of the Study}

The present study employed a quasi-experimental pre-test/post-test control group design. There were two groups, one as an experimental group that received collocation activities as the treatment and a control group which received traditional method of vocabulary instruction. The design for this study was quasi-experimental in nature, because the classroom groups were already in place and had to be intact. In order to have a strong quasi-experimental design, 
internal threats to validity were controlled by making use of pretesting. To be confident that there would be no significant difference among the participants of the experimental group and control group regarding the variable under exploration, both groups were pre-tested at the commencement of the study.

\subsection{Participants}

The participants in this study were 60 female students at the intermediate level of English proficiency, studying EFL whose first language was Farsi. Convenience sampling was applied in the present study to select 60 female students who were studying at Pardis Institute in Lahijan, Iran. The range of their age was between 16-22 years. The study was carried out at Pardis Institute in Lahijan. Since the students were assigned to two different classes based on the institute's placement test, no homogeneity test was administered beforehand. They were divided into two groups of 30 .

\subsection{Instruments}

The research instruments in this study included pre-test and post-test. They were researcher-made vocabulary tests piloted by the researchers before conducting the actual study. They included 25 multiple choice vocabulary items extracted from Top Notch 1 coursebook authored by Saslow and Ascher (2015). The post-test was the same test in the pre-test but in order to control the test wise-ness, the order of items was changed. The validity of the tests was confirmed by two experienced teachers, and their reliability was estimated using Cronbach's alpha $(\alpha=0.81)$. First of all, to find out students' vocabulary knowledge, a researcher made pre-test was administered and the second test was used as the post-test after the treatment sessions.

\subsection{Procedure}

The study took place in the academic year 2017-2018. Two intermediate classes $(n=60)$ were sampled and considered as the control $(n=30)$ and the experimental groups $(n=30)$. At the beginning of the study, the researcher-made vocabulary test as the pre-test was administered to both groups. For 10 weeks, the new words of the units of the Top Notch 1 course-book authored by Saslow and Ascher (2015) were taught by collocations and using corpus-based activities in the experimental group. The experimental group was presented the new vocabulary through their collocations which were thought to be the most frequent ones. The unknown word was written in a circle in the center of the board. Then, collocates especially which were thought to be the most frequent ones were written around that word. The researchers, themselves, were teaching both the control and experimental groups during the treatment.

In the experimental group, the students first read the passage and then the researchers presented the new vocabulary items. They presented multiple suitable collocates for each word. In this way, students were learning a new word through its collocations. After presenting all the new words through the use of collocates, five comprehension questions related to the passage were asked and answered to make the task more meaningful. A test containing gapfilling exercises wherein the students were supposed to choose the answer from the list of words was practiced for newly learned vocabulary at the end of each week. Meanwhile, the researchers used traditional techniques of teaching vocabulary including explanation, definition, and translation of the words out of the context by referring to the list of words in the form of marginal glosses available in the textbook in the control group. At the end of the experiment, the second researcher-made vocabulary test was administered as the post-test in order to check the probable significant improvement of vocabulary knowledge in the participants.

\subsection{Data Collection}

The required data in this study were collected in two phases. In the first phase, the participants of both control and experimental groups attended in a pre-test exam. The pre-test was a researcher-made vocabulary test piloted by the researchers before conducting the actual study. It included 25 multiple choice vocabulary items extracted from Top Notch 1 course-book authored by Saslow and Ascher (2015). The second phase of data collection was giving the posttest to the participants. It was the same test in the pre-test but in order to control the test wise-ness, the order of items was changed. All participants attended in the post-test exam.

\subsection{Data Analysis}

To analyze the data of this study, the statistical package for the social sciences (SPSS) version 20 was used. In order to check the homogeneity of the participants in vocabulary knowledge at the beginning of the study, an IndependentSamples t-test was run on the data obtained from the pre-test. To test the normality assumption, Kolmogorov-Smirnov 
test was employed and to find the answer to the research question, the researchers' made post-test was administered in order to assess the learners' vocabulary knowledge. Finally, the means of two groups were compared via independent sample t-test statistically. The alpha level for significance testing was set at .05 for all inferential statistics.

\section{Results}

This section is dedicated to the presentation of findings from the data gathered by the researchers. First, the data are presented descriptively and later on inferentially. Two parametric methods of paired and independent sample t-test were used here. In this method, subjects were assigned into two groups of one control and one experimental and their scores were analyzed in the pre-test and post-test. Thus, in the first part of this section, descriptive data are used to present mean and standard deviation in all groups. In the second part, inferential statistics are applied to analyze the null hypothesis of the study. This study investigated the effect of collocation activities on the learners' knowledge of vocabulary. In order to answer the research question of this study, statistical analyses were carried out. Firstly, the normal distribution of data has been checked as in Table 1.

Table 1. Normal distribution of the scores of vocabulary test

\begin{tabular}{lllll}
\hline & & \multicolumn{2}{l}{ Shapiro-Wilk } & \\
\cline { 4 - 5 } & Groups & Statistic & Df & Sig. \\
\hline Pre-test & Experimental & .925 & 29 & .264 \\
& Control & .915 & 29 & .115 \\
\hline Post-test & Experimental & .910 & 29 & .073 \\
& Control & .916 & 29 & .134 \\
\hline
\end{tabular}

As Table 1 shows, p-values for the pre-test and post-test of the collocation group are .264 and .073, respectively. Correspondingly, the same p-values for the control group equals with .115 and .134, respectively. Since the values are more than 0.05 , the normality assumptions were meet. Descriptive statistics of the learners who received collocation activities are provided as follows.

Table 2. Descriptive statistics for the vocabulary tests of experimental group

\begin{tabular}{llllc}
\hline & Mean & N & Std. Deviation & Std. Error Mean \\
\hline Pre-test & 18.3500 & 30 & 2.92345 & .76573 \\
\hline Post-test & 23.7500 & 30 & 4.35423 & 1.34245 \\
\hline
\end{tabular}

Table 2 shows the growth in the learners' mean scores from the pre-test $(\mathrm{M}=18.35, \mathrm{SD}=2.92)$ to the post-test $(\mathrm{M}=23.75, \mathrm{SD}=4.35)$, which confirms that collocation activities could probably result in improving the learners' vocabulary knowledge. Figure 1 demonstrates the difference between the mean scores of the pre- and post-test. 


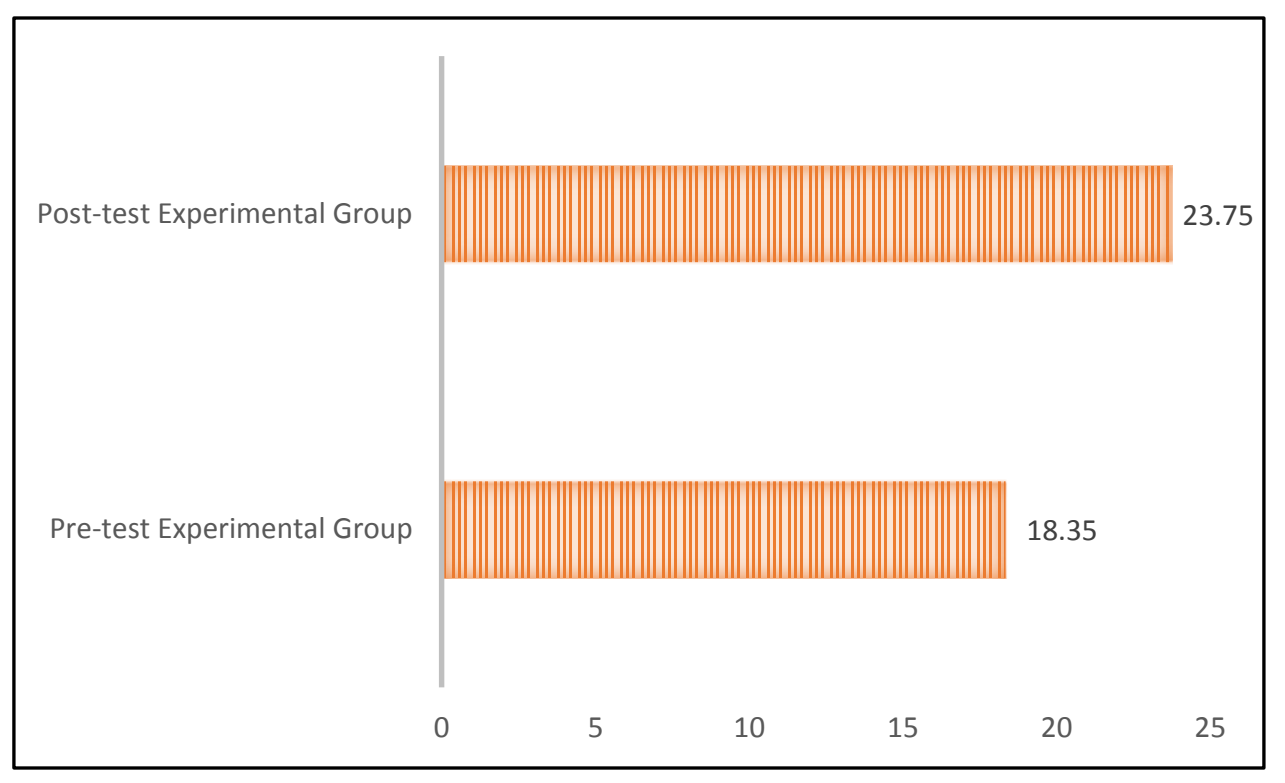

Figure 1. Vocabulary knowledge tests of the experimental group

In order to check whether there was a significant difference between the learners' mean scores in the pre- and posttest of vocabulary knowledge, paired samples t-test was run (Table 3).

Table 3. Paired-Samples t-test for the vocabulary knowledge of experimental group

\begin{tabular}{|c|c|c|c|c|c|c|c|c|}
\hline & \multicolumn{6}{|c|}{ Paired Differences } & \multirow[b]{3}{*}{ Df } & \multirow[b]{3}{*}{ Sig. (2-tailed) } \\
\hline & \multirow[b]{2}{*}{ Mean } & \multirow{2}{*}{\multicolumn{2}{|c|}{$\begin{array}{c}\text { Std. } \\
\text { Std. DeviationMean }\end{array}$}} & \multicolumn{3}{|c|}{$\begin{array}{l}95 \% \text { Confidence Interval of } \\
\text { the Difference } \\
\text { r }\end{array}$} & & \\
\hline & & & & Lower & Upper & $\mathrm{t}$ & & \\
\hline $\begin{array}{l}\text { Pre-test } \\
\text { test }\end{array}$ & Post- -5.40000 & 3.76134 & .58435 & -6.76846 & -3.87045 & -5.234 & 58 & .001 \\
\hline
\end{tabular}

The results of paired samples t-tests indicated that the level of significance is less than $.05(\mathrm{p}=.001 \mathrm{c} \mathrm{Df}=58 \mathrm{t} \mathrm{t}=-5.23)$, highlighting the significant difference between the experimental group's mean scores of the pre- and post-test in their vocabulary knowledge. The mean difference is -05.40 . Therefore, receiving collocation activities improved the learners' vocabulary knowledge. After comparing the pre- and post-test of the learners who benefited from collocation activities, the experimental and control groups were taken into account. Table 4 shows the two groups' performance on the occasion of the vocabulary knowledge pre-test.

Table 4. Descriptive statistics for the pre-test of the experimental and control groups

\begin{tabular}{llllll}
\hline & Groups & $\mathrm{N}$ & Mean & Std. Deviation & Std. Error Mean \\
\hline Pre-test & Experimental & 30 & 18.3500 & 2.92345 & .76573 \\
& Control & 30 & 17.9500 & 3.24567 & .64568 \\
\hline
\end{tabular}


Descriptive statistics of the pre-test of the experimental and the control group denote that the experimental $(\mathrm{M}=18.35$, $\mathrm{SD}=2.92)$ and control groups $(\mathrm{M}=17.95, \mathrm{SD}=3.24)$ mean scores acted almost similarly before the treatment sessions. Figure 2 shows the comparison of the two groups' performance for the pre-test.

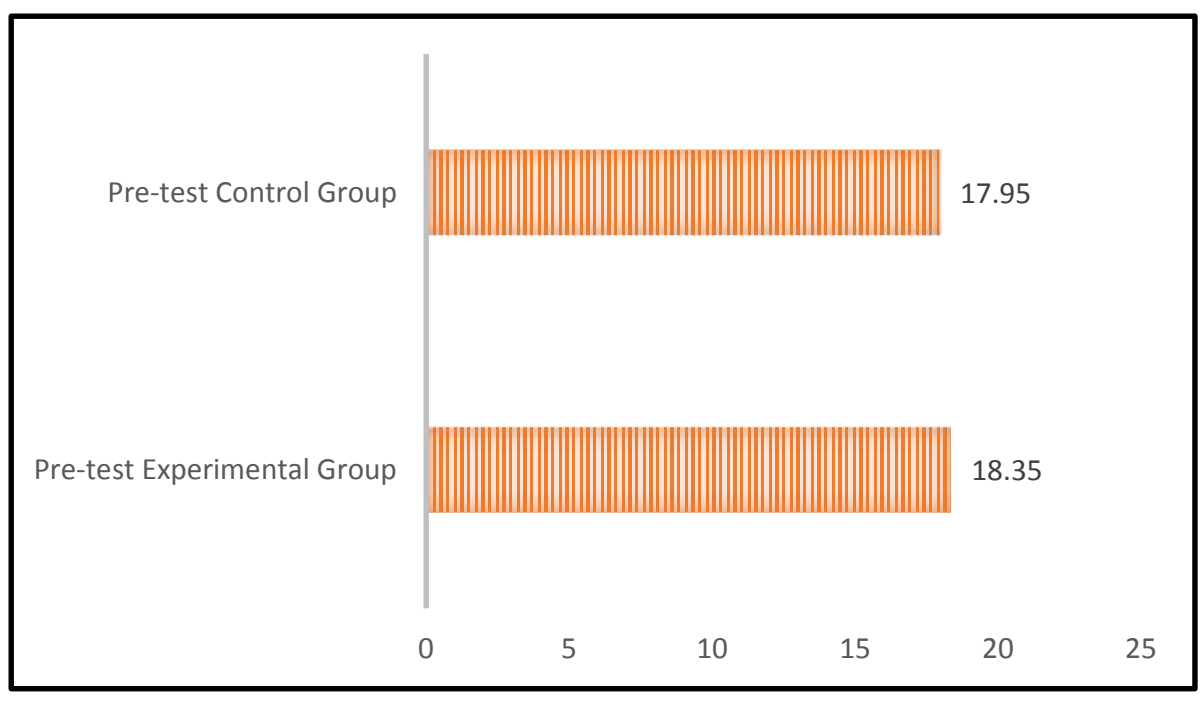

Figure 2. Pre-test scores of the experimental and the control groups

In order to figure out the significance level of the difference between the pre-test scores of experimental group and the control one, independent samples t-test was run (Table 5).

Table 5. Independent-Samples t-test for the pre-test scores of the experimental group and the control group

\begin{tabular}{|c|c|c|c|c|c|c|c|c|c|}
\hline & $\begin{array}{l}\text { Levene } \\
\text { Equalit }\end{array}$ & $\begin{array}{l}\text { Test } \\
\text { Varian }\end{array}$ & r t-test & Equali & f Means & & & & \\
\hline & & & & & Sig. & -Mean & Std. Erro & $\begin{array}{l}95 \% \text { Confi } \\
\text { Difference } \\
\end{array}$ & ce Interval of the \\
\hline & F & Sig. & $\mathrm{t}$ & Df & tailed) & Difference & Difference & Lower & Upper \\
\hline Equal variances assumed & 5.367 & .012 & .386 & 58 & .786 & .40235 & 1.23657 & -1.45890 & 2.25876 \\
\hline $\begin{array}{l}\text { Equal variances } \\
\text { not assumed }\end{array}$ & & & .367 & 51.67 & .687 & .40235 & 1.68745 & -1.68312 & 2.64389 \\
\hline
\end{tabular}

As Table 5 shows, $\mathrm{p}$-value from Leven's test is below .05 ( $\mathrm{p}=.012)$, which does not meet the equality of the variance for the two groups. The result of independent samples t-test demonstrates that the level of significance is more than $.05(\mathrm{p}=.687, \mathrm{df}=01.67, \mathrm{t}=.36)$, revealing no significant difference between the vocabulary knowledge of the two groups. The mean difference is 0.40 , representing very little difference. The descriptive statistics for the vocabulary knowledge post-tests of the experimental and control group are shown in Table 6. 
Table 6. Descriptive statistics for the post-test of the experimental and the control groups

\begin{tabular}{llllll}
\hline & Groups & N & Mean & Std. Deviation & Std. Error Mean \\
\hline Post-test & Experimental & 29 & 23.75000 & 4.35423 & 1.34245 \\
& Control & 29 & 19.43764 & 3.48476 & .68234 \\
\hline
\end{tabular}

Table 6 shows much difference between the post-test mean scores of experimental group $(M=23.75, S D=4.35)$ and the control group $(M=19.43, \mathrm{SD}=3.48)$. The mean difference of the two groups is illustrated in Figure 3.

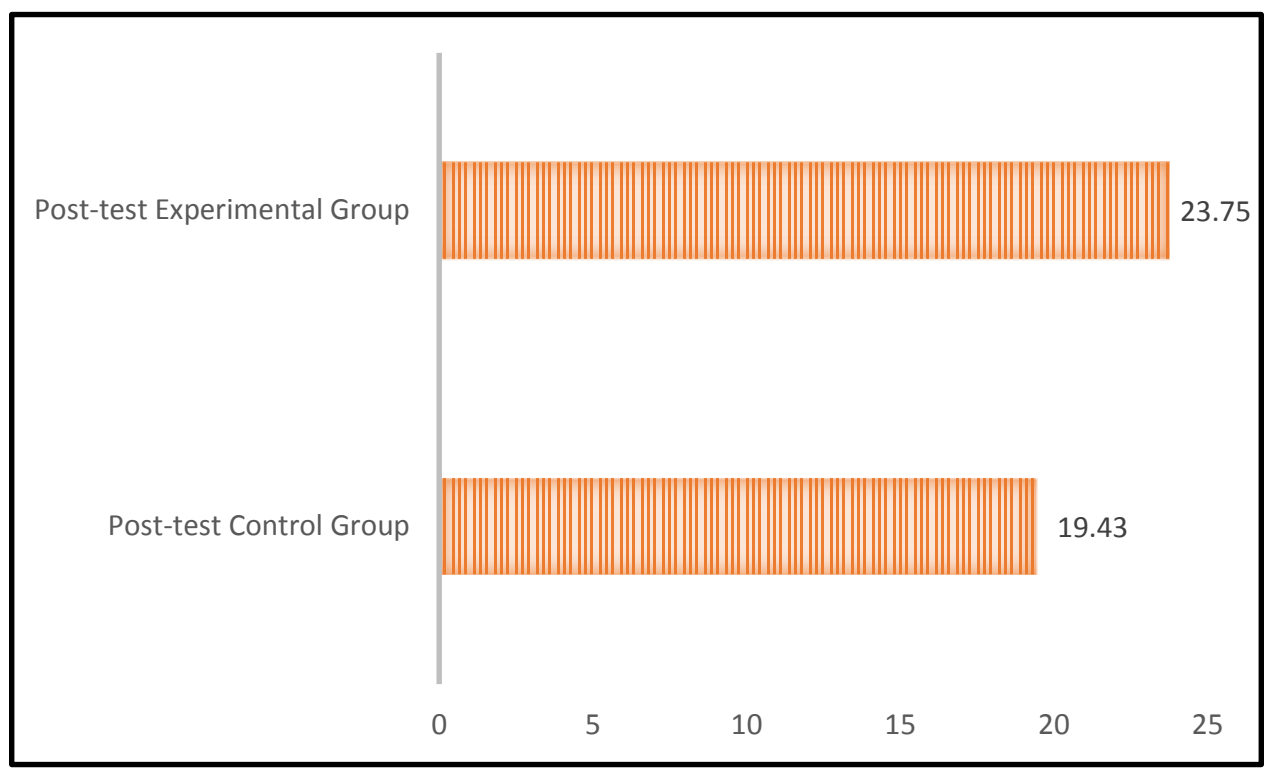

Figure 3. Post-test scores of the experimental and the control group

In order to inferentially compare the experimental and control learners' vocabulary knowledge after the treatment sessions, independent samples t-test was run (Table 7).

Table 7. Independent Samples t-test for the post-test scores of the experimental and the control groups

\begin{tabular}{|c|c|c|c|c|c|c|c|c|c|}
\hline & \multicolumn{9}{|c|}{$\begin{array}{l}\text { Levene's Test for } \\
\text { Equality of Variances t-test for Equality of Means }\end{array}$} \\
\hline & \multirow[b]{2}{*}{$\mathrm{F}$} & \multirow[b]{2}{*}{ Sig. } & \multirow[b]{2}{*}{$\mathrm{T}$} & \multirow[b]{2}{*}{ Df } & \multirow{2}{*}{$\begin{array}{l}\text { Sig. } \\
\text { tailed) }\end{array}$} & \multirow{2}{*}{$\begin{array}{l}\text { 2-Mean } \\
\text { Difference }\end{array}$} & \multirow{2}{*}{$\begin{array}{l}\text { Std. Err } \\
\text { Difference }\end{array}$} & \multicolumn{2}{|c|}{$\begin{array}{l}95 \% \text { Confidence Interval of } \\
\text { the Difference }\end{array}$} \\
\hline & & & & & & & & Lower & Upper \\
\hline Equal variances assume & $d 12.347$ & .002 & 4.146 & 58 & .002 & 4.32121 & 1.24356 & 1.36578 & 7.21687 \\
\hline $\begin{array}{l}\text { Equal variances no } \\
\text { assumed }\end{array}$ & & & 4.411 & $\bullet 1.265$ & .002 & 4.32121 & 1.26578 & 1.14325 & 7.11234 \\
\hline
\end{tabular}

As to Table 7, p-value resulted from Levene's test is less than $.05(p=.002)$, which reveals that the variance of the scores for the two groups was not equal. The second line of the above table demonstrates that the significance level is 
less than $.05(\mathrm{p}=.002, \mathrm{Df}=01.26, \mathrm{t}=4.41)$, showing significant difference between the experimental group and the control one. The mean difference is 4.32 , which is rather high. Therefore, it can be concluded that the null hypothesis of this study is rejected and collocation activities could result in significant improvement in the learners' vocabulary knowledge.

\section{Discussion}

This section discusses the main findings of this study, which is in line with examining the effect of collocation activities on the Iranian intermediate EFL learners' vocabulary knowledge. In fact, the goal is to find possible relationship between the findings of the current study with the previous studies carried out with respect to collocation activities and its impact on the EFL learners' improvement in vocabulary knowledge, which is the main focus of this study.

Based on the quantitative findings of the present study through measuring the pre- and post- test scores of the learners in the experimental and control group, it was found that the experimental group significantly outperformed the control group after the treatment, demonstrating that using collocation activities was quite successful in helping the learners improve their vocabulary knowledge. In other words, the experimental group which was taught through collocation activities in comparison with the control group, underwent the traditional method of vocabulary teaching. This finding proved that collocation activities can be accounted for at the service of teaching vocabulary within communicative context. This finding has been supported by the findings of Hsu (2005), Rahimi and Momeni (2012), Khodareza and Ashouri (2016), and Keshavarz and Taherian (2018) who concluded that the experimental group who were taught via lexical collocation outperformed the control group who were taught through traditional teaching method, suggesting that teaching collocation resulted in language proficiency improvement.

The findings obtained from this study imply that it would be beneficial to teach vocabulary via collocations. Despite the fact that the collocation technique was regarded as a new technique for the EFL learners, they had never been instructed through a vocabulary learning technique even similar to that, the experimental group's scores were superior to the control group's scores in all of the vocabulary tests. It can also be stated that they could get higher scores providing that they had some more time to become accustomed with the new technique. This means that if they had more time, they would get used to learn the new words by their collocations and score even higher. This may motivate less experienced teachers to use such a new and useful technique into their EFL classrooms to change the present situation and get more confidence using scientific findings to their instruction. This finding is in agreement with the findings of the study of Gitsaki et al. (2000) who stated that it is not easy for learners to learn collocations in a very short period of time. That is, learners need more time to learn collocations effectively. The reason is that they need pragmatic knowledge and there are no standard rules for combining words. Therefore, it is recommended that learners should have more exposure to collocations and these words should be taught as an important component of vocabulary instruction.

The findings of the study of Eyraud, Giles, Koenig, and Stoller (2000) are in line with the findings of the present study. Based on the findings of the above researchers, learners can increase their vocabulary knowledge through rethinking instructional priorities and taking some important steps like providing a vocabulary rich setting to support the incidental learning of vocabulary and providing learners with opportunities for vocabulary reusing in various meaningful contexts. As a result, it can be stated that the learners' knowledge of the new words and their different meanings in different collocations can provide such opportunities. The results of this study are in accordance with the findings of Tovar Viera (2017) who said that teachers' teaching should provide opportunities for learners' vocabulary learning that helps learners use them in different contexts by focusing on communication rather than uttering wellformed sentences. Vocabulary acquisition needs meaningful interactions that allow learners to familiarize with the appropriate language use in a particular context. Learners can increase their vocabulary knowledge through contact with the form-meaning connections of words that assist learners in learning words effectively and productively in different meaningful and communicative situations.

There are three important processes that can lead to the recall of vocabulary. They are noticing, retrieval, and creative use. Noticing is paying attention to the vocabulary and being aware of it. Therefore, it is concluded that introducing various groups of new words can assist learners in noticing them and going through the first process to recall words. The expected impacts of teaching new words through their most frequent collocations are easily observed. Vocabulary instruction by new collocation technique helps learners to keep in mind that learning the vocabulary items through collocation technique is much better than using the conventional techniques for learning them (Nation, 2001). Despite 
different types of lexical instruction Iranian EFL learners have, they are not highly motivated to learn vocabulary effectively. This results in the incomplete recognition and usage of vocabulary which negatively affects their performance in all language skills. The findings of this study are in accordance with the researchers' anticipations since this new technique seemed both motivating and useful to EFL learners.

Moreover, Hsu (2010) investigated the impacts of collocation instruction on Taiwanese English majors' reading comprehension and vocabulary learning. The findings of his study indicated that collocation instruction improved the learners' vocabulary learning. This finding has been supported by the findings of this research in that collocation teaching can be regarded as a valuable technique for improving vocabulary knowledge. Nevertheless, contrary to the findings of the present research, teaching words by their collocations for the learners did not result in better learning and retention. Although teaching new words through collocations did not create any statistically significant difference in learning and recall of new words, Altınok (2000) concluded that collocates of words should be taught when introducing new vocabulary because a lot of learners have serious problems in finding appropriate collocates for new words.

On the whole, this research has showed that vocabulary instruction by means of collocations is an effective technique which has a significant role in the EFL learners' expansion of vocabulary recall. At the same time, the findings of the current study have attained similar results as the previous studies on collocation such as Hsu (2010), Lewis, (2000), and Yazdandoos, AmalSaleh, and Kafipour (2014), who emphasized its positive impact on foreign language learning in many facets.

\section{Conclusion}

This study indicated that teaching vocabulary through collocations improved the vocabulary knowledge more than traditional techniques. Collocations are considered as a significant part of L2 vocabulary improvement. The knowledge of collocations is the core of the knowledge of language. Consequently, teachers of English could be encouraged to spend some more classroom time for this kind of teaching in their classes and to allocate more importance to the application of certain learning strategies in vocabulary development in order to make vocabulary learning process more effectual and more significant for the students. Vocabulary knowledge and the procedure of vocabulary remembering are significant factors in learning a foreign language. Vocabulary as a component that connects the four skills of speaking, listening, reading, and writing altogether, plays a significant role in helping language learners to communicate well in the new language. Despite having good knowledge of grammar and vocabulary, a lot of Iranian EFL learners have serious difficulties with collocations in terms of receptive and productive skills. This is pertinent to the insufficient importance to collocational patterns in textbooks and the kind of instructions EFL learners receive.

Learners' communication and language skills are closely related to their knowledge of collocation. It is hoped that this research can arouse more researchers' attention to learners' learning of collocations and problems in collocations. It can be stated that instruction on collocation should be encouraged to replace traditional vocabulary instruction for the aim of improving EFL learners' vocabulary knowledge. At the pedagogical level, the results of this study and the collocation activities which are going to be used in this study can serve as guides for ways in which to revise existing techniques to more efficiently tap into the cognitive processes of second language vocabulary learners. In this way, this study can contribute to foreign language vocabulary learning research, curriculum and materials development, pedagogical practice, and self-study methods. EFL teachers should help their learners overcome their learners' problems by designing instruction methods to focus on what they need.

It is useful for teachers to present the activities that include teaching collocation into their lessons, all designed to help their learners develop collocational proficiency. Teachers should use appropriate activities for teaching collocation. Activities should be suitable for the kind of collocation being taught as well as the needs and abilities of learners. Teachers should teach learners useful learning strategies that will help them to independently develop their collocational knowledge beyond the classes. Therefore, collocations should be paid enough attention particularly in EFL contexts and the instruction of them should take more time. The idea that collocates of words should be taught when presenting new vocabulary is still worth considering, because specifically Iranian EFL learners have serious problems in finding suitable collocates for words.

The findings of the present study can be advantageous in practice regarding the effect of collocation activities on educational setting as explained in the following. The findings of the study suggest some productive implications in 
terms of teaching and learning vocabulary through collocation activities. The role of collocation activities instruction should be recognized as an appropriate methodology, which seems to be beneficial for both learners and teachers. The study can be of great significance regarding teaching vocabulary in educational settings such as institutes. Learners seem to benefit from collocation instruction. Many learners appear to be worried about vocabulary knowledge in the process of language learning. Being taught by collocation activities, learners can overcome their vocabulary difficulties since they are exposed to an interactive vocabulary learning environment in which they seem to be more interested to enhance their learning opportunities. In order to improve EFL learners' knowledge of collocations, teachers should adjust their curriculum to incorporate the instruction of collocations into their teaching methods. EFL learners should be aware of their inadequate collocational knowledge. They should try to build up their collocation size to improve their vocabulary knowledge.

\section{References}

Allen, F. V. (1983). Techniques in teaching vocabulary. Oxford: Oxford University Press. https://trove.nla.gov.au/version/45034368

Altınok, Ş. Í. (2000). Teaching vocabulary using collocations versus using definitions in EFL classes. Unpublished master's thesis, Íhsan Doğramac1 Bilkent University, Ankara, Turkey. repository.bilkent.edu.tr/handle/11693/18208

Dornyei, Z. (2007). Research methods in applied linguistics. New York: Oxford University Press. 336 pages. https://journals.lib.unb.ca/index.php/CJAL/article/download/19893/21727

Eyraud, K., Giles, G., Koenig, S., \& Stoller, F. L. (2000). The word wall approach: Promoting L2 vocabulary learning. English Teaching Forum, 38(3), 2-11. https://eric.ed.gov/?id=EJ650621

Ghezelseflou, M., \& Seyedrezaei, S. H. (2015). An investigation on the impact of teaching vocabulary through collocations on the vocabulary retention of EFL learners. International Journal of Basic Sciences \& Applied Research, 4(3), 162-170. https://docplayer.net/22894079-An-investigation-on-the-impact-of-teachingvocabulary-through-collocations-on-the-vocabulary-retention-of-efl-learners.html Accessed 18 December 2019.

Ghonsooli, B., Pishgaman, R., \& Mahjoobi, F. (2008). The impact of collocational instruction on the writing skill of Iranians EFL learners: A case of product and process study. Iranian EFL Journal, 1(1), 36-59. https://www.mjselt.com > IEFL Journals > IEFL 2008 Accessed 28 January 2019.

Gitsaki, C., Daigaku, N. S., \& Taylor, R. P. (2000). English collocations and their place in the EFL classroom. http://www.hum.nagoya-cu.ac.jp/taylor/publications/collocations.htm

Gorjian, B., Moosavinia, R., Ebrahimi, K., Asgari, P., \& Hydarei, A. (2011). The impact of asynchronous computerassisted language learning approaches on English as a Foreign Language high and low achievers' vocabulary retention and recall. Computer Assisted Language Learning, 24(5), 383-391. doi: $\underline{10.1080 / 09588221.2011 .552186}$

Hsu, J. Y. (2010). The effects of collocation instruction on the reading comprehension and vocabulary learning of Taiwanese college English majors. Asian EFL Journal, 12(1), 47-87. https://www.asian-efljournal.com/main-journals/the-effects-of-collocation-instruction-on-the-reading-comprehension-andvocabulary-learning-of-college-english-majors/ Accessed 18 December 2019.

Hsu, L. C. (2005). The effect of lexical collocation instruction on Taiwanese college EFL learners listening comprehension. Unpublished master thesis, National Kaohsiung First University of Science and Technology, Taiwan.

Jaén, M. M. (2007). A corpus-driven design of a test for assessing the ESL collocational competence of university students. International Journal of English Studies, 7(2), 127-147. http://revistas.um.es/ijes/article/view/49031

Keshavarz, M. H., \& Taherian, P. (2018). The effect of explicit instruction of collocations on EFL learners' language proficiency. Hacettepe Üniversitesi Eğitim Fakültesi Dergisi (H. U. Journal of Education). doi: 10.16986/HUJE.2018038632 
Khoda Reza, M., \& Ashouri, S. (2016). The effect of lexical collocation instruction on intermediate EFL learners' vocabulary size. Indian Journal of Fundamental and Applied Life Sciences, (S1), 416-425. www.cibtech.org/sp.ed/j1s/2016/01/j1s.htm

Krashen, S. (1989). We acquire vocabulary and spelling by reading: Additional evidence for the input hypothesis. The Modern Language Journal, 73(4), 440-464. doi: 10.2307/326879 https://www.jstor.org/stable/326879

Lewis, M. (2000). Teaching collocation: Further developments in the lexical approach. London: Language Teaching Publications. https://www.goodreads.com/book/show/2460684.Teaching_Collocation

Lien, H. Y. (2003). The effects of collocation instruction on the reading comprehension of Taiwanese college students. Unpublished doctoral dissertation, Indiana University of Pennsylvania, Pennsylvania.

Nation, I. S. P. (2001). Learning vocabulary in another language. Cambridge: Cambridge University Press. catdir.loc.gov/catdir/samples/cam031/2001269892.pdf

Nattinger, J. (1988). Some current trends in vocabulary teaching. In Carter, M., \& M. McCarthy (Eds.), Vocabulary and language teaching (PP. 62-82). London: Longman. www.sciepub.com/reference/252879

Nattinger, J., \& DeCarrio, J. S. (1992). Lexical phrases and language teaching. Oxford: Oxford University Press. https://www.amazon.com/Lexical-Phrases-Language-Teaching.../dp/0194371646

Nowzan, S. Z., \& Baryaji, T. (2013). The impact of retrieval task on learning vocabulary of Iranian EFL learners. Journal of Advances in English Language Teaching, 1(1), 24-30. europeanscience.com/jaelt/article/view/77ww.european-science.com/jaelt

Rahimi, R., \& Momeni, G. (2012). The effect of teaching collocations on English language proficiency. Procedia Social and Behavioral Sciences, 31, 37-42. https://doi.org/10.1016/j.sbspro.2011.12.013

Saslow, J., \& Ascher, A. (2015). Top Notch 1 (3rd Edition). Pearson Education ESL. https://www.amazon.com/TopNotch-3rd-Joan-Saslow/dp/0133928934

Shin, D., \& Nation, P. (2008). Beyond single words: the most frequent collocations in spoken English. ELT Journal, 62(4), 339-348. http://dx.doi.org/10.1093/elt/ccm091

Skrzypek, A. (2009). Language and culture: Attitudes towards and perceptions of English L2 acquisition among adult Polish migrants in Ireland. In B. Geraghty, \& J. E. Conacher (Eds.), Cultures in contact: Contemporary Issues in Language Use and Language Learning. London: Continuum.

Tovar Viera, R. (2017). The importance of vocabulary knowledge in the production of written texts: a case study on EFL language learners. Revista Tecnológica ESPOL-RTE, 30(3), 89-105. https://www.researchgate.net/publication/316148312

Waring, R. (2002). Scales of vocabulary knowledge in second language vocabulary assessment. Appeared in Kiyo: The occasional papers of Notre Dame Seishin University, Japan. https://wenku.baidu.com/view/43e085c289eb172ded63b7d5.html

Yazdandoost, Z., AmalSaleh, E., \& Kafipour, R. (2014). The relationship among collocation knowledge and listening, speaking, reading, and writing proficiency of Iranian EFL learners. Language, Individual \& Society, 8, 408419. https://www.scientific-publications.net/get/1000006/1408972464185312.pdf

Yunus, M. M., Salehi, H., \& Amini, M. (2016). Impact of using CALL on Iranian EFL learners' vocabulary knowledge. English Language Teaching, 9(1), 173-187. doi:10.5539/elt.v9n1p173 